\title{
Serotonin: a platelet hormone modulating cardiovascular disease
}

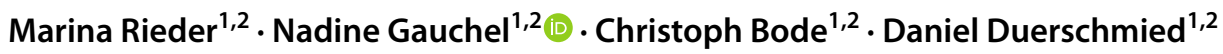

Accepted: 30 October 2020 / Published online: 5 November 2020

(c) The Author(s) 2020

\begin{abstract}
Cardiovascular diseases and depression are significant health burdens and increasing evidence suggests a causal relationship between them. The incidence of depression among patients suffering from cardiovascular disease is markedly elevated, and depression itself is an established cardiovascular risk factor. Serotonin 5-hydroxytryptamin (5-HT), a biogenic amine acting as a neurotransmitter and a peripheral hormone, is involved in the pathogenesis of both, cardiovascular disease and depression. Novel cardiovascular functions of 5-HT have recently been described and will be summarized in this review. 5-HT has a broad spectrum of functions in the cardiovascular system, yet the clinical or experimental data are partly conflicting. There is further research needed to characterize the clinical effects of 5-HT in particular tissues to enable targeted pharmacological therapies.
\end{abstract}

Keywords Serotonin $\cdot 5$-hydroxytryptamin $\cdot$ Platelets $\cdot$ Cardiovascular disease

\section{Highlights}

- Depression and cardiovascular diseases are significant health burdens.

- Serotonin, acting as a neurotransmitter and a biogenic amine is involved in the pathogenesis of depression and cardiovascular disease.

- Novel cardiovascular functions of serotonin have recently been described.

- This review focuses on the role of serotonin in atherosclerosis, myocardial infarction, heart failure, thrombosis and arterial hypertension.

Marina Rieder and Nadine Gauchel have contributed equally.

Nadine Gauchel

nadine.gauchel@universitaets-herzzentrum.de

1 Department of Cardiology and Angiology I, Faculty of Medicine, Heart Center Freiburg University, University of Freiburg, Hugstetter Strasse 55, 79106 Freiburg, Germany

2 Department of Medicine III (Interdisciplinary Medical Intensive Care), Medical Center, Faculty of Medicine, University of Freiburg, Freiburg, Germany

\section{Serotonin}

Serotonin 5-hydroxytryptamin (5-HT) was discovered more than 70 years ago and first described as a vasoconstrictor [1]. Since then, multiple functions of 5-HT emerged, all conducted via signaling through one of the so far 15 known distinct 5 -HT receptors $[2,3]$ or by covalent binding to different effector proteins, named "serotonylation" [4]. In regard of cardiovascular diseases, the receptor subtypes 5-HT1B, 5-HT2A, 5-HT2B, 5-HT4 and 5-HT7 are of particular interest. 5-HT1B, 5-HT2A, 5-HT2B and 5-HT7 are expressed on smooth muscle and endothelial cells of arteries and veins, regulating vascular tone. 5-HT2A is additionally located on platelets and involved in activation and aggregation, and it can also be found on cardiomyocytes and fibroblasts. 5-HT4, expressed in cardiac atria and ventricle conducts positive inotropic and lusitropic effects but may also trigger arrhythmias (reviewed in [5]).

\section{Serotonin synthesis}

5-HT is derived from the essential amino acid 1-tryptophan [6]. The biosynthesis of 5-HT is regulated by two isoforms of the enzyme tryptophanhydroxylase (Tph), Tph1 and Tph2 [7]. Tph 2 is expressed in the brain stem, where it regulates 5-HT synthesis in the central nervous system [8]. The effects 
mediated by central 5-HT are very complex: It is involved in the regulation of mood [9], appetite [9], circadian rhythm [10] and sexual drive. Disturbances in this system appear to be closely linked to psychiatric diseases like depressive or anxiety disorders [11].

However, the vast majority of 5-HT can be found in the peripheral system [12]. Peripheral 5-HT is synthesized by enterochromaffine cells in the gut by tryptophan hydroxylase I and released into blood plasma [13]. Most of the circulating 5-HT is taken up by platelets via the 5-HT transporter SERT [14]. Platelets, as the main circulating reservoir of 5-HT, store it in their dense granules in high concentrations and release it upon activation [4]. As platelets are not able to synthesize 5-HT, chronic intake of selective serotonin reuptake inhibitors (SSRIs) and therefore long-term blockage of SERT results in a depletion of platelet 5-HT storage [15] (Fig. 1).

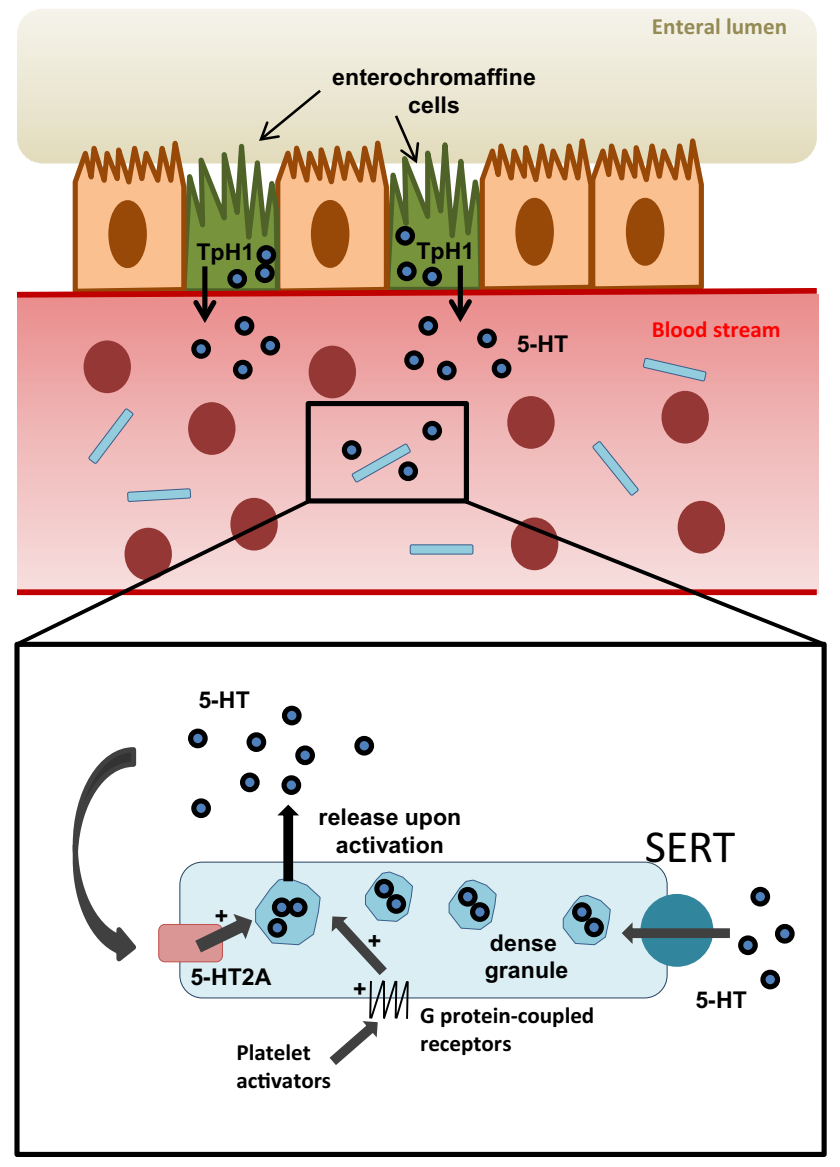

Fig. 1 Enterochromaffine cells (EC-cells) in the gut express Tph1 and synthesize the majority of peripheral serotonin (5-HT). EC-cells release 5-HT into the blood plasma, where it is taken up by platelets (blue rectangles) via SERT. Platelets, as the main circulating reservoir, store 5-HT in their dense granules. Upon activation, platelet dense granules release 5-HT. 5-HT can amplify the release of dense granules via activation of the 5-HT2A receptor
In peripheral tissues, 5-HT is involved in a broad variety of functions including regulation of vascular tone [16], gut motility [17], hemostasis [18], and immune responses [19-21]. Due to the above described broad distribution of receptors in the cardiovascular system, 5-HT plays a major role in a variety of cardiovascular diseases and elevated 5-HT concentrations have been described in e.g. arterial hypertension [22], carotid atherosclerosis [23] or coronary artery disease $[24,25]$.

\section{Serotonin in hemostasis and thrombosis}

Platelets play a major role in hemostasis and thrombus formation. 5-HT influences platelet activation and aggregation by enhancing multiple pathways of primary hemostasis: Primary hemostasis is induced by circulating von Willebrand-Factor (vWF) binding to exposed collagen at sites of vascular endothelial damage. Platelets are able to adhere on vWF via glycoprotein (GP) I $\beta \alpha$ expressed on their surface [26]. This stable binding allows the interaction of collagen with GP IIb/IIIa on platelets, leading to platelet activation [27]. Upon activation, a number of intracellular signaling mechanisms, mostly G-protein-dependent, lead to an exocytosis of dense granules. These release a broad variety of molecules, such as ADP, ATP, $\mathrm{Ca}^{2+}$ and 5-HT. As platelets themselves express corresponding receptors for these released substances including 5-HT receptor $2 \mathrm{~A}$ and 3 , dense granule secretion leads to a feedback loop enhancing platelet aggregation and activation at the site of vascular damage (reviewed in [28]). Additionally, serotonin is taken up in the cytoplasm and transamidated to small GTPases by transglutaminases during activation and aggregation of platelets, a process called serotonylation [29]. This triggers the further release of dense granules [29]. Another mechanism how 5-HT influences platelet activation and aggregation is by altering $\mathrm{N}$-glycan expression on the platelet surface [30]. When the serotonin transporter is lacking, an agonist-induced $\mathrm{Ca}^{2+}$ influx through store operated $\mathrm{Ca} 2+$ entry (SOCE), integrin activation, degranulation and aggregation responses to glycoprotein VI and C-type lectin like receptor 2 (CLEC-2) is reduced in platelets [31].

The importance of 5-HT in the process of platelet activation and aggregation was shown in animal models: 5-HT infused mice suffer from enhanced platelet aggregation [30, $32,33]$. This can be normalized by the intake of SSRI [30, 32] or a 5-HT2a receptor antagonist [30, 33]. Tph1 deficient mice with low peripheral 5-HT levels exhibit a mildly prolonged bleeding time due to an impaired release of dense granules. This results in a reduced risk of arterial thrombosis and experimental venous thromboembolism [29]. In an in vivo dog model of spontaneous occlusive coronary 
thrombus formation, increased plasma serotonin levels could be measured during thrombus formation [34]. This could be reproduced in a model of carotid artery thrombosis in rats, where a 15 fold increase of 5-HT was measured [35].

In humans, SERT-levels are associated with venous thrombosis [36] and in patients suffering from carcinoid syndrome, elevated 5-HT levels are associated with a hypercoagulable status [28]. Epidemiologic data suggests a role of 5HT or 5HT-reuptake inhibitors in the development of venous thrombosis. Patients with depression were reported to have higher incidences of venous thromboembolism in general and the use of tricyclic antidepressants, selective serotonin reuptake inhibitors and other antidepressants were each associated with an increased VTE risk [37] The mechanisms behind the role of serotonin in venous thrombosis have not been addressed so far.

\section{Serotonin in atherosclerosis}

Clinical studies on cardiovascular effects of depletion of platelet 5-HT by intake of SSRIs are inconclusive. On the one hand, some did not find any increase or even an ameliorated cardiovascular risk [38-41], whereas others reported a worse cardiovascular risk profile after SSRI intake [42-44].

Blockage of the 5-HT2A receptor by the antagonist sarpogrelate retards the progression of atherosclerosis in a rabbit model by upregulation of eNOS and presumably antiproliferative effects on smooth muscle cells and macrophages [45]. Consistent with these findings, sarpogrelate has a therapeutic effect an patients with atherosclerosis obliterans [46] and critical limb ischemia [47]. In a collective of diabetic patients, sarpogrelate decreased coronary artery plaque volume [48].

Consistent with that, animal studies showed that chronic intake of Fluoxetine enhances atherosclerosis by promoting myeloid binding capacity and increasing leukocyte-endothelial interactions [49].

\section{The role of serotonin in myocardial infarction}

Depletion of platelet serotonin storages by long-term administration of serotonin reuptake inhibitors reduces the risk of MI [50-52]. Consistent with that, a previous study revealed that possessing the LL genotype of SERT resulting in a higher expression and activity of SERT leads to a significantly increased risk for MI [53]. Moreover, serotonin levels are associated with coronary artery disease and occurrence of cardiac events [24]. Mechanistically, serotonin is thought to promote these adverse effects by enhancing platelet aggregation and vasoconstriction of diseased coronary arteries (reviewed in [54]).

Myocardial infarction leads to platelet activation, subsequently resulting in a further release of 5-HT from platelets, which in turn worsens myocardial ischemia and promotes reperfusion injury [55]. Recently, our group showed that the 5-HT-mediated aggravation of reperfusion injury is due to enhanced neutrophil degranulation leading to enhanced inflammation in the infarct area [15].

Animal studies on pharmacological blockage of 5-HT or its receptors led to conflicting results, mainly due to a broad variety in experimental setups, animal models and serotonin receptor antagonists used. The 5-HT2 receptor antagonist LY53857 did not influence infarct size in a canine model of myocardial infarction [56]. Contrary to these in vivo results, it was reported that LY53857 increased reperfusion injury ex vivo [57], whereas it was reduced by several other 5-HT2 receptor antagonists [58]. The combined $\mathrm{Ca} 2+$ and 5-HT2 receptor antagonist neopamil reduced infarction size in pigs [59] and the 5-HT2A receptor antagonist sarpogrelate did the same in rabbits by inhibiting 5-HT release [55].

\section{Serotonin in heart failure}

The 5-HT4 receptor is expressed in atria and ventricles at a very low level under physiologic conditions. In heart failure, the expression of 5-HT4 is markedly upregulated, and stimulation of 5-HT4 receptor increases myocardial contractility and relaxation [60]. Overall, the mechanisms of action resembles that from beta-adrenoceptors through a pathway involving CAMP and PKA-mediated phosphorylation of proteins of $\mathrm{Ca}^{2+}$ handling, resulting in enhanced contractility through increased $\mathrm{Ca}^{2+}$ availability $[61,62]$. But as the increased contractility via cAMP is energy-intensive, a blockage of this pathway e.g. by beta-adrenoceptor antagonists is beneficial in heart failure patients. It was thought that a blockageof 5-HT4 could be beneficial in the same way [61]. Yet treatment of heart failure in rats with the 5-HT4 antagonist piboserid resulted in only small beneficial effects [63] and human studies were disappointing due to a high number of adverse events [64].

\section{Serotonin and hypertension}

Elevated 5-HT levels have been reported for patients with arterial hypertension [65, 66] and these have an altered platelet surface profile [67].

Peripheral administration of 5-HT leads to a triphasic response of blood pressure: Due to the stimulation of 5-HT3 receptors on vagal afferents, initially a short vasodepressive phase occurs. Then, activation of 5-HT2A receptors 
leads to a vasopressive phase and finally, the activation of 5-HT7 receptors on smooth vascular muscle cells leads to another vasodepression [28]. Central administration of 5-HT can cause hypertension via activation of 5-HT2 receptors or hypotension by stimulation of 5-HT1A receptors. The antihypertensive drug Urapidil acts via antagonism on central adrenoceptors but also via agonism on central 5-HT1A receptors [28].

\section{Concluding remarks}

5-HT has a broad spectrum of functions in the cardiovascular system, yet the clinical or experimental data are partly conflicting. There is further research needed to characterize the clinical effects of 5-HT in particular tissues to enable targeted pharmacological therapies.

Author contributions MR and NG wrote the first draft of the manuscript. DD and CB supported in review design and literature research.

Funding Open Access funding enabled and organized by Projekt DEAL. M. Rieder is funded by the IMM-PACT-Programme for Clinician Scientists, Faculty of Medicine, University of Freiburg, funded by the Deutsche Forschungsgemeinschaft (DFG, German Research Foundation)—413517907.

\section{Compliance with ethical standards}

Conflict of interest All authors declared no conflicts of interests. All authors agreed to publish this manuscript.

Open Access This article is licensed under a Creative Commons Attribution 4.0 International License, which permits use, sharing, adaptation, distribution and reproduction in any medium or format, as long as you give appropriate credit to the original author(s) and the source, provide a link to the Creative Commons licence, and indicate if changes were made. The images or other third party material in this article are included in the article's Creative Commons licence, unless indicated otherwise in a credit line to the material. If material is not included in the article's Creative Commons licence and your intended use is not permitted by statutory regulation or exceeds the permitted use, you will need to obtain permission directly from the copyright holder. To view a copy of this licence, visit http://creativecommons.org/licenses/by/4.0/.

\section{References}

1. Rapport MM, Green AA, Page IH (1948) Serum vasoconstrictor, serotonin; isolation and characterization. J Biol Chem 176:1243-1251

2. McCorvy JD, Roth BL (2015) Structure and function of serotonin G protein-coupled receptors. Pharmacol Ther 150:129-142. https ://doi.org/10.1016/j.pharmthera.2015.01.009

3. David DJ, Gardier AM (2016) The pharmacological basis of the serotonin system: application to antidepressant response. L'Encephale 42:255-263. https://doi.org/10.1016/j.encep .2016.03.012
4. Walther DJ, Peter J-U, Winter S et al (2003) Serotonylation of small GTPases is a signal transduction pathway that triggers platelet alpha-granule release. Cell 115:851-862

5. Ayme-Dietrich E, Lawson R, Da-Silva S et al (2019) Serotonin contribution to cardiac valve degeneration: new insights for novel therapies? Pharmacol Res 140:33-42. https://doi.org/10.1016/j. phrs.2018.09.009

6. Bender DA (1983) Biochemistry of tryptophan in health and disease. Mol Aspects Med 6:101-197. https://doi.org/10.1016/00982997(83)90005-5

7. Swami T, Weber HC (2018) Updates on the biology of serotonin and tryptophan hydroxylase. Curr Opin Endocrinol Diabetes Obes 25:12-21. https://doi.org/10.1097/MED.0000000000000383

8. Mohammad-Zadeh LF, Moses L, Gwaltney-Brant SM (2008) Serotonin: a review. J Vet Pharmacol Ther 31:187-199. https:// doi.org/10.1111/j.1365-2885.2008.00944.x

9. Strasser B, Gostner JM, Fuchs D (2016) Mood, food, and cognition: role of tryptophan and serotonin. Curr Opin Clin Nutr Metab Care 19:55-61. https://doi.org/10.1097/MCO.000000000000023 7

10. Morin LP (1999) Serotonin and the regulation of mammalian circadian rhythmicity. Ann Med 31:12-33

11. Żmudzka E, Sałaciak K, Sapa J, Pytka K (2018) Serotonin receptors in depression and anxiety: insights from animal studies. Life Sci 210:106-124. https://doi.org/10.1016/j.lfs.2018.08.050

12. Veenstra-VanderWeele J, Anderson GM, Cook EH (2000) Pharmacogenetics and the serotonin system: initial studies and future directions. Eur J Pharmacol 410:165-181. https://doi.org/10.1016/ s0014-2999(00)00814-1

13. Walther DJ, Peter J-U, Bashammakh S et al (2003) Synthesis of serotonin by a second tryptophan hydroxylase isoform. Science 299:76. https://doi.org/10.1126/science.1078197

14. Mercado CP, Kilic F (2010) Molecular mechanisms of SERT in platelets: regulation of plasma serotonin levels. Mol Interv 10:231-241. https://doi.org/10.1124/mi.10.4.6

15. Mauler M, Herr N, Schoenichen C et al (2019) Platelet serotonin aggravates myocardial ischemia/reperfusion injury via neutrophil degranulation. Circulation 139:918-931. https://doi.org/10.1161/ CIRCULATIONAHA.118.033942

16. Myers JH, Mecca TE, Webb RC (1985) Direct and sensitizing effects of serotonin agonists and antagonists on vascular smooth muscle. J Cardiovasc Pharmacol 7:S44-S48. https://doi. org/10.1097/00005344-198500077-00014

17. Sanger GJ (1996) 5-Hydroxytryptamine and functional bowel disorders. Neurogastroenterol Motil 8:319-331. https://doi. org/10.1111/j.1365-2982.1996.tb00270.x

18. Duerschmied D, Bode C (2009) The role of serotonin in haemostasis. Hamostaseologie 29:356-359

19. Shajib MS, Khan WI (2015) The role of serotonin and its receptors in activation of immune responses and inflammation. Acta Physiol Oxf Engl 213:561-574. https://doi.org/10.1111/apha.12430

20. Schoenichen C, Bode C, Duerschmied D (2019) Role of platelet serotonin in innate immune cell recruitment. Front Biosci Landmark Ed 24:514-526

21. Mauler M, Bode C, Duerschmied D (2016) Platelet serotonin modulates immune functions. Hamostaseologie 36:11-16. https ://doi.org/10.5482/HAMO-14-11-0073

22. Frishman WH, Grewall P (2000) Serotonin and the heart. Ann Med 32:195-209. https://doi.org/10.3109/07853890008998827

23. Ban Y, Watanabe T, Miyazaki A et al (2007) Impact of increased plasma serotonin levels and carotid atherosclerosis on vascular dementia. Atherosclerosis 195:153-159. https://doi.org/10.1016/j. atherosclerosis.2006.09.005

24. Vikenes K, Farstad M, Nordrehaug JE (1999) Serotonin is associated with coronary artery disease and cardiac events. Circulation 100:483-489. https://doi.org/10.1161/01.cir.100.5.483 
25. van den Berg EK, Schmitz JM, Benedict CR et al (1989) Transcardiac serotonin concentration is increased in selected patients with limiting angina and complex coronary lesion morphology. Circulation 79:116-124. https://doi.org/10.1161/01.cir.79.1.116

26. Ruggeri ZM, Mendolicchio GL (2007) Adhesion mechanisms in platelet function. Circ Res 100:1673-1685. https://doi. org/10.1161/01.RES.0000267878.97021.ab

27. Denis CV, Wagner DD (2007) Platelet adhesion receptors and their ligands in mouse models of thrombosis. Arterioscler Thromb Vasc Biol 27:728-739. https://doi.org/10.1161/01.ATV.00002 59359.52265 .62

28. Fraer M, Kilic F (2015) Serotonin: a different player in hypertension-associated thrombosis. Hypertens Dallas Tex 65:942-948. https://doi.org/10.1161/HYPERTENSIONAHA.114.05061

29. Walther DJ, Peter J-U, Winter S et al (2003) Serotonylation of small GTPases is a signal transduction pathway that triggers platelet alpha-granule release. Cell 115:851-862. https://doi. org/10.1016/s0092-8674(03)01014-6

30. Mercado CP, Quintero MV, Li Y et al (2013) A serotonin-induced $\mathrm{N}$-glycan switch regulates platelet aggregation. Sci Rep 3:2795. https://doi.org/10.1038/srep02795

31. Wolf K, Braun A, Haining EJ et al (2016) Partially defective store operated calcium entry and hem(ITAM) signaling in platelets of serotonin transporter deficient mice. PLoS ONE 11:e0147664. https://doi.org/10.1371/journal.pone.0147664

32. Ziu E, Mercado CP, Li Y et al (2012) Down-regulation of the serotonin transporter in hyperreactive platelets counteracts the prothrombotic effect of serotonin. J Mol Cell Cardiol 52:1112-1121. https://doi.org/10.1016/j.yjmcc.2012.02.004

33. Przyklenk K, Frelinger AL, Linden MD et al (2010) Targeted inhibition of the serotonin 5HT2A receptor improves coronary patency in an in vivo model of recurrent thrombosis. J Thromb Haemost JTH 8:331-340. https://doi.org/10.1111/j.1538-7836.2009.03693 . $\mathrm{X}$

34. Benedict CR, Mathew B, Rex KA et al (1986) Correlation of plasma serotonin changes with platelet aggregation in an in vivo dog model of spontaneous occlusive coronary thrombus formation. Circ Res 58:58-67. https://doi.org/10.1161/01.res.58.1.58

35. Wester P, Dietrich WD, Prado R et al (1992) Serotonin release into plasma during common carotid artery thrombosis in rats. Stroke 23:870-875. https://doi.org/10.1161/01.str.23.6.870

36. Llobet D, Vallvé C, Tirado I et al (2019) VAMP8 and serotonin transporter levels are associated with venous thrombosis risk in a Spanish female population. Results from the RETROVE Project. Thromb Res 181:99-105. https://doi.org/10.1016/j.throm res.2019.07.023

37. Parkin L, Balkwill A, Sweetland S et al (2017) Antidepressants, depression, and venous thromboembolism risk: large prospective study of UK women. J Am Heart Assoc. https://doi.org/10.1161/ JAHA. 116.005316

38. Coupland C, Hill T, Morriss R et al (2016) Antidepressant use and risk of cardiovascular outcomes in people aged 20 to 64: cohort study using primary care database. BMJ 352:11350. https://doi. org/10.1136/bmj.i1350

39. Pizzi C, Rutjes AWS, Costa GM et al (2011) Meta-analysis of selective serotonin reuptake inhibitors in patients with depression and coronary heart disease. Am J Cardiol 107:972-979. https:// doi.org/10.1016/j.amjcard.2010.11.017

40. Stewart JC, Perkins AJ, Callahan CM (2014) Effect of collaborative care for depression on risk of cardiovascular events: data from the IMPACT randomized controlled trial. Psychosom Med 76:29-37. https://doi.org/10.1097/PSY.0000000000000022

41. Kimmel SE, Schelleman H, Berlin JA et al (2011) The effect of selective serotonin re-uptake inhibitors on the risk of myocardial infarction in a cohort of patients with depression. Br J Clin Pharmacol 72:514-517. https://doi.org/10. 1111/j.1365-2125.2011.04008.x

42. Coupland C, Dhiman P, Morriss R et al (2011) Antidepressant use and risk of adverse outcomes in older people: population based cohort study. BMJ 343:d4551. https://doi.org/10.1136/bmj.d4551

43. Biffi A, Scotti L, Corrao G (2017) Use of antidepressants and the risk of cardiovascular and cerebrovascular disease: a meta-analysis of observational studies. Eur J Clin Pharmacol 73:487-497. https://doi.org/10.1007/s00228-016-2187-x

44. Rieckmann N, Kronish IM, Shapiro PA et al (2013) Serotonin reuptake inhibitor use, depression, and long-term outcomes after an acute coronary syndrome: a prospective cohort study. JAMA Intern Med 173:1150-1151. https://doi.org/10.1001/jamaintern med.2013.910

45. Hayashi T, Sumi D, Matsui-Hirai $\mathrm{H}$ et al (2003) Sarpogrelate $\mathrm{HCl}$, a selective 5-HT2A antagonist, retards the progression of atherosclerosis through a novel mechanism. Atherosclerosis 168:23-31. https://doi.org/10.1016/S0021-9150(03)00054-6

46. Ren S, Qian S, Wang W et al (2013) Prospective study of sarpogrelate hydrochloride on patients with arteriosclerosis obliterans. Ann Thorac Cardiovasc Surg Off J Assoc Thorac Cardiovasc Surg Asia 19:30-34. https://doi.org/10.5761/atcs. oa.12.02061

47. Takahara M, Kaneto H, Katakami N et al (2014) Effect of sarpogrelate treatment on the prognosis after endovascular therapy for critical limb ischemia. Heart Vessels 29:563-567. https://doi. org/10.1007/s00380-013-0334-1

48. Lee D-H, Chun EJ, Hur JH et al (2017) Effect of sarpogrelate, a selective 5-HT2A receptor antagonist, on characteristics of coronary artery disease in patients with type 2 diabetes. Atherosclerosis 257:47-54. https://doi.org/10.1016/j.atherosclerosis .2016.12.011

49. Rami M, Guillamat-Prats R, Rinne P et al (2018) Chronic intake of the selective serotonin reuptake inhibitor fluoxetine enhances atherosclerosis. Arterioscler Thromb Vasc Biol 38:1007-1019. https://doi.org/10.1161/ATVBAHA.117.310536

50. Sauer WH, Berlin JA, Kimmel SE (2003) Effect of antidepressants and their relative affinity for the serotonin transporter on the risk of myocardial infarction. Circulation 108:32-36. https://doi. org/10.1161/01.CIR.0000079172.43229.CD

51. Kim Y, Lee YS, Kim MG et al (2019) The effect of selective serotonin reuptake inhibitors on major adverse cardiovascular events: a meta-analysis of randomized-controlled studies in depression. Int Clin Psychopharmacol 34:9-17. https://doi.org/10.1097/ YIC.0000000000000238

52. Schlienger RG, Fischer LM, Jick H, Meier CR (2004) Current use of selective serotonin reuptake inhibitors and risk of acute myocardial infarction. Drug Saf 27:1157-1165. https://doi. org/10.2165/00002018-200427140-00006

53. Fumeron F, Betoulle D, Nicaud V et al (2002) Serotonin transporter gene polymorphism and myocardial infarction: etude cas-témoins de l'infarctus du myocarde (ECTIM). Circulation 105:2943-2945. https://doi.org/10.1161/01.cir.0000022603.92986 .99

54. Doggrell SA (2003) The role of 5-HT on the cardiovascular and renal systems and the clinical potential of 5-HT modulation. Expert Opin Investig Drugs 12:805-823. https://doi. org/10.1517/13543784.12.5.805

55. Shimizu Y, Minatoguchi S, Hashimoto K et al (2002) The role of serotonin in ischemic cellular damage and the infarct sizereducing effect of sarpogrelate, a 5-hydroxytryptamine-2 receptor blocker, in rabbit hearts. J Am Coll Cardiol 40:1347-1355. https ://doi.org/10.1016/S0735-1097(02)02158-7

56. Simpson PJ, Schelm JA, Jakubowski JA, Smallwood JK (1991) The role of serotonin (5HT2) receptor blockade in myocardial 
reperfusion injury: effects of LY53857 in a canine model of myocardial infarction. J Pharmacol Exp Ther 258:979-985

57. Yang BC, Virmani R, Nichols WW, Mehta JL (1993) Platelets protect against myocardial dysfunction and injury induced by ischemia and reperfusion in isolated rat hearts. Circ Res 72:11811190. https://doi.org/10.1161/01.RES.72.6.1181

58. Grover GJ, Sargent CA, Dzwonczyk S et al (1993) Protective effect of serotonin (5-HT2) receptor antagonists in ischemic rat hearts. J Cardiovasc Pharmacol 22:664-672. https://doi. org/10.1097/00005344-199310000-00022

59. Hohlfeld T, Braun M, Strobach H, Schrör K (1994) Protection of reperfused ischemic pig myocardium by nexopamil, a new combined $\mathrm{Ca} 2+$ and serotonin antagonist. J Cardiovasc Pharmacol 23:922-931. https://doi.org/10.1097/00005344-199406000-00010

60. Brattelid T, Qvigstad E, Moltzau LR et al (2012) The cardiac ventricular 5-HT4 receptor is functional in late foetal development and is reactivated in heart failure. PLoS ONE 7:e45489. https:// doi.org/10.1371/journal.pone.0045489

61. Levy FO, Qvigstad E, Krobert KA et al (2008) Effects of serotonin in failing cardiac ventricle: signalling mechanisms and potential therapeutic implications. Neuropharmacology 55:1066-1071. https://doi.org/10.1016/j.neuropharm.2008.07.010

62. Birkeland JAK, Swift F, Tovsrud N et al (2007) Serotonin increases L-type $\mathrm{Ca} 2$ + current and SR Ca2 + content through 5-HT4 receptors in failing rat ventricular cardiomyocytes. Am
J Physiol Heart Circ Physiol 293:H2367-H2376. https://doi. org/10.1152/ajpheart.01375.2006

63. Birkeland J, Sjaastad K, Brattelid I et al (2007) Effects of treatment with a 5-HT4 receptor antagonist in heart failure. Br J Pharmacol 150:143-152. https://doi.org/10.1038/sj.bjp.0706966

64. Kjekshus JK, Torp-Pedersen C, Gullestad L et al (2009) Effect of piboserod, a 5-HT4 serotonin receptor antagonist, on left ventricular function in patients with symptomatic heart failure. Eur $\mathbf{J}$ Heart Fail 11:771-778. https://doi.org/10.1093/eurjhf/hfp087

65. Brenner B, Harney JT, Ahmed BA et al (2007) Plasma serotonin levels and the platelet serotonin transporter. J Neurochem 102:206-215. https://doi.org/10.1111/j.1471-4159.2007.04542.x

66. Biondi ML, Agostoni A, Marasini B (1986) Serotonin levels in hypertension. J Hypertens Suppl Off J Int Soc Hypertens 4:S39-S41

67. Minuz P, Patrignani P, Gaino S et al (1979) (2004) Determinants of platelet activation in human essential hypertension. Hypertens Dallas Tex 43:64-70. https://doi.org/10.1161/01.HYP.00001 05109.44620.1B

Publisher's Note Springer Nature remains neutral with regard to jurisdictional claims in published maps and institutional affiliations. 